\title{
Determination of Vanadium in Urine by Electrothermal Atomic Absorption Spectrometry Using Hot Injection and Preconcentration Into the Graphite Tube
}

\author{
Kelly G. Fernandes ${ }^{a, b}$, Ana Rita A. Nogueira ${ }^{*, b}$, José A. Gomes Neto ${ }^{c}$ and Joaquim A. Nóbrega ${ }^{a}$ \\ ${ }^{a}$ Departamento de Química, Universidade Federal de São Carlos, CP 676, 13560-970 São Carlos - SP, Brazil \\ ${ }^{b}$ Embrapa Pecuária Sudeste, CP 339, 13560-970 São Carlos - SP, Brazil \\ ${ }^{c}$ Instituto de Química, Universidade Estadual Paulista, CP 355, 14560-970 Araraquara - SP, Brazil
}

\begin{abstract}
É proposto um procedimento para a determinação direta de vanádio em amostras de urina por espectrometria de absorção atômica com atomização eletrotérmica em forno de grafite usando injeção à quente e pré-concentração dentro do tubo de grafite. Três aliquotas de $60 \mu \mathrm{L}$ foram injetados seqüencialmente dentro do atomizador pré-aquecido a uma temperatura de $110^{\circ} \mathrm{C}$. As etapas de secagem e pirólise foram repetidas após cada injeção. Às amostras de urina foram adicionados o modificador químico fluoreto de bário $\left(100 \mathrm{mg} \mathrm{L}^{-1}\right)$ e o surfactante Triton X-100 $\left(0,3 \% \mathrm{v} \mathrm{v}^{-1}\right)$. A vazão da amostra durante a injeção dentro do tubo pré-aquecido foi de $0,5 \mu \mathrm{L} \mathrm{s}^{-1}$. Os limites de detecção e de quantificação sem pré-concentração foram, respectivamente, 0,54 e 1,82 $\mu \mathrm{g} \mathrm{L}^{-1}$, e com pré-concentração 0,11 e $0,37 \mu \mathrm{g} \mathrm{L}^{-1}$. O teste de adição e recuperação foi empregado em amostras de urina para avaliar a exatidão do procedimento proposto. Os valores de recuperação obtidos variaram de 96,0 a 103,0\% para as adições de 0,8 a $3,5 \mu \mathrm{g} \mathrm{L} \mathrm{L}^{-1} \mathrm{~V}$. O procedimento proposto possibilita a determinação de vanádio sem nenhum pré-tratamento e com mínima diluição da amostra.
\end{abstract}

In this work it was developed a procedure for the determination of vanadium in urine samples by electrothermal atomic absorption spectrometry using successive injections for preconcentration into a preheated graphite tube. Three $60 \mu \mathrm{L}$ volumes were sequentially injected into the atomizer preheated to a temperature of $110{ }^{\circ} \mathrm{C}$. Drying and pyrolysis steps were carried out after each injection. A chemical modifier, barium difluoride $\left(100 \mathrm{mg} \mathrm{L}^{-1}\right)$, and a surfactant, Triton $\mathrm{X}-100\left(0.3 \% \mathrm{v} \mathrm{v}^{-1}\right)$, were added to the urine sample. When injecting into a hot graphite tube, the sample flow-rate was $0.5 \mu \mathrm{L}$ $\mathrm{s}^{-1}$. The limits of detection and quantification were 0.54 and 1.82 without preconcentration, and 0.11 and $0.37 \mu \mathrm{g} \mathrm{L}^{-1}$ with preconcentration, respectively. The accuracy of the procedure was evaluated by an addition-recovery experiment employing urine samples. Recoveries varied from 96.0 to $103 \%$ for additions ranging from 0.8 to $3.5 \mu \mathrm{g} \mathrm{L}^{-1} \mathrm{~V}$. The developed procedure allows the determination of vanadium in urine without any sample pretreatment and with minimal dilution of the sample.

Keywords: vanadium, urine, ETAAS, preconcentration, hot injection

\section{Introduction}

Vanadium is an essential trace element for plants and animals which acts in the synthesis of chlorophyll and promotes the growth of young animals. Vanadium compounds are toxic in high concentrations or after long periods of exposure. ${ }^{1,2}$ There are also $\mathrm{V}$ compounds that exhibit chemotherapeutic effects in the treatment of leukemia ${ }^{1}$ and recent studies showed promising application in management of diabetes. ${ }^{3-6}$

\footnotetext{
* e-mail: anarita@cppse.embrapa.br
}

However, the investigation of physiological effects caused by vanadium is hindered due to the severe difficulties for its determination in tissues and biological fluids. Concentrations of vanadium in body fluids are lower than those in tissue samples, and contamination during their collection, storage, preservation, and treatment of the sample is the major limitation for accurate determination. ${ }^{7-12}$ Rigorous analytical quality control of all steps is mandatory.

A variety of methods have been used for vanadium determination including UV-visible spectrophotometry, fluorimetry, voltammetry, ion-selective electrodes, gas chromatography, neutron activation analysis, X-ray 
fluorescence spectrometry, emission spectrometry and electrothermal atomic absorption spectrometry (ETAAS). ${ }^{13,14}$ Electrothermal AAS has been used for determination of vanadium in different types of samples. Owing to the levels $\left(\mu \mathrm{g} \mathrm{L}^{-1}\right)$ of vanadium in urine, it is generally necessary to adopt a preconcentration procedure, such as ionexchange, ${ }^{15,16}$ coprecipitation of vanadium with iron(II) hydroxide ${ }^{17,18}$ or complexation and extraction with an organic solvent such as ammonium pyrrolidinedithiocarbamate (APDC) in MIBK, ${ }^{19}$ cupferron in MIBK,,${ }^{7,920} \mathrm{~N}$ cinnamoyl-N-(2,3-xylyl)hydroxylamine in carbon tetrachloride ${ }^{21}$ or 8 -hydroxyquinoline in MIBK. ${ }^{22}$ These methods of sample preconcentration are time consuming, require a relatively large sample volume for each measurement and are prone of losses or contamination.

The direct preconcentration procedure using hot injection in ETAAS has been applied for determining vanadium in water samples, ${ }^{21,22}$ urine after extraction of vanadium with cupferron in MIBK, ${ }^{9}$ and milk samples. ${ }^{14}$ These procedures offer advantages compared to conventional ones including reduced sample preparation time, decreased possibility of losses of analyte during the preconcentration step, and reduced possibility of sample contamination caused by manipulation or added reagents.

In the work here described it was developed a procedure for vanadium direct determination in urine samples using successive injections into a preheated graphite tube.

\section{Experimental}

\section{Instrumentation}

Measurements were carried out using a Varian Model 800 atomic absorption spectrometer equipped with a graphite furnace atomizer, GTA 100 autosampler and transverse Zeeman effect background correction (Varian, Mulgrave, Australia). A vanadium hollow cathode lamp was employed as radiation source operating at $20 \mathrm{~mA}$. Absorbance signals were measured using the $318.4 \mathrm{~nm}$ line and a spectral resolution of $0.2 \mathrm{~nm}$. Pyrolytic coated graphite tubes (Part Number 63-100011-00, Varian) were used throughout. All signals were measured as integrated absorbance with an integration time of $4.3 \mathrm{~s}$. The temperature program for the atomizer is shown in Table 1 for an injected volume of $60 \mu \mathrm{L}$.

\section{Reagents and materials}

All dilutions were made using ultra pure water (resistivity $18.2 \mathrm{M} \Omega \mathrm{cm}$ ) obtained in a Milli-Q water
Table 1. Graphite Furnace heating program with preconcentration ${ }^{\mathrm{a}}$

\begin{tabular}{cccc}
\hline Step & $\begin{array}{c}\text { Temperature } \\
\left({ }^{\circ} \mathrm{C}\right)\end{array}$ & $\begin{array}{c}\text { Time (s) } \\
(\text { Ramp, Hold })\end{array}$ & $\begin{array}{c}\text { Ar flow-rate } \\
\left.(\mathrm{L} \mathrm{min})^{-1}\right)\end{array}$ \\
\hline 1 & 110 & 1,60 & 3 \\
2 & 300 & 10,20 & 3 \\
3 & 1800 & 5,20 & 3 \\
4 & 2700 & $3,1.3$ & 0 (read) \\
5 & 2700 & 1,3 & 3 \\
\hline
\end{tabular}

a Sample flow-rate: $0.5 \mu \mathrm{L} \mathrm{s}^{-1}$.

purification system (Millipore, Bedford MA, USA). A stock standard solution containing $1000 \mathrm{mg} \mathrm{L}^{-1} \mathrm{~V}$ (Spex, Metuchen NJ, USA) was used. Triton X-100 (Merck, Darmstadt, Germany) was also used. Throughout experimental work double sub-boiling distilled $\mathrm{HNO}_{3}$ was used. This acid was prepared by sub-boiling distillation of $\mathrm{HNO}_{3}$ concentrated (Merck) using a Milestone apparatus model subPUR (Sorisole, Italy). A solution of $\mathrm{BaF}_{2}$ was used as chemical modifier by dissolving $100 \mathrm{mg}$ of the salt $(99.99 \%$ purity, Aldrich, Milwaukee WI, USA) in $100 \mathrm{~mL}$ of ultrapure water. Argon (99.999\% purity, White Martins, Sertãozinho SP, Brazil) was used as purge gas.

All glassware, pipettes, micropipette tips, auto-sampler cups, and polypropylene containers were acid washed with $0.14 \mathrm{~mol} \mathrm{~L}^{-1} \mathrm{HNO}_{3}$ for $24 \mathrm{~h}$ and thoroughly rinsed 3 times with deionized water before use.

\section{Procedure}

Volumes of $600 \mu \mathrm{L}$ of urine sample, $100 \mu \mathrm{L} 1000 \mathrm{mg} \mathrm{L}^{-1}$ $\mathrm{BaF}_{2}$, and $100 \mu \mathrm{L} 3 \% \mathrm{v} \mathrm{v}^{-1}$ Triton X-100 were transferred to the autosampler cup, and then diluted to $1000 \mu \mathrm{L}$ with distilled-deionized water. Three successive $60 \mu \mathrm{L}$ aliquots were injected into the atomizer, inserting drying and ashing steps between each injection. When injecting into a hot graphite tube, the sample flow-rate was $60 \mu \mathrm{L}$ in $120 \mathrm{~s}$ $\left(0.5 \mu \mathrm{L} \mathrm{s}^{-1}\right)$. The graphite furnace was heated according to the program showed in Table 1 and the integrated absorbance signal was measured.

\section{Results and Discussion}

\section{Electrothermal behavior of vanadium}

One of the difficulties for determining vanadium by ETAAS is the formation of refractory carbides during the heating cycle. This effect causes a pronounced loss of sensitivity. This problem can be circumvented by using pyrolytic graphite tubes and by adding a chemical modifier. In a previous work on vanadium determination in milk, the use of $\mathrm{BaF}_{2}$ as chemical modifier was 
successfully demonstrated. Probably the positive effect on sensitivity is caused by the formation of volatile compounds between vanadium and fluoride. ${ }^{14}$

In the developed work the electrothermal behavior of $\mathrm{V}$ was studied in the following media: $0.014 \mathrm{~mol} \mathrm{~L}^{-1} \mathrm{HNO}_{3}$, urine, and urine in the presence of $\mathrm{NH}_{4} \mathrm{NO}_{3}$ and $\mathrm{BaF}_{2}$ as chemical modifiers. These chemical modifiers were chosen to facilitate the formation of volatile salts with the urine matrix and to improve vanadium atomization. In the absence of these modifiers, it was observed an intense deposition of salts in the tube orifice and graphite electrodes mainly when working with less diluted urine samples. The conventional heating program for the graphite tube atomizer is shown in Table 2 for an injected volume of $30 \mu \mathrm{L}$. The effect of $\mathrm{NH}_{4} \mathrm{NO}_{3}$ and $\mathrm{BaF}_{2}$ as chemical modifiers was evaluated. For a sample volume of $30 \mu \mathrm{L}$ it was added $300 \mu \mathrm{g} \mathrm{NH}_{4} \mathrm{NO}_{3}$. Taking into account that the effect caused by $\mathrm{BaF}_{2}$ on $\mathrm{V}$ atomization in urine samples is less trivial, different masses of this salt were added and the results obtained can be observed in Figure 1. Best sensitivity was attained when using $6 \mu \mathrm{g} \mathrm{BaF}_{2}$. Pyrolysis and atomization curves for $\mathrm{V}$ without (Figure 2) and with chemical modifiers (Figure 3) were obtained. The optimum pyrolysis and atomization

Table 2. Graphite Furnace heating conventional program

\begin{tabular}{cccc}
\hline Step & $\begin{array}{c}\text { Temperature } \\
\left({ }^{\circ} \mathrm{C}\right)\end{array}$ & $\begin{array}{c}\text { Time (s) } \\
(\text { Ramp, Hold })\end{array}$ & $\begin{array}{c}\text { Ar flow-rate } \\
\left(\mathrm{L} \mathrm{min}^{-1}\right)\end{array}$ \\
\hline 1 & 95 & 5,40 & 3 \\
2 & 120 & 10,30 & 3 \\
3 & 1800 & 5,20 & 3 \\
4 & 2700 & $2,1.3$ & 0 (read) \\
5 & 2700 & 1,3 & 3 \\
\hline
\end{tabular}

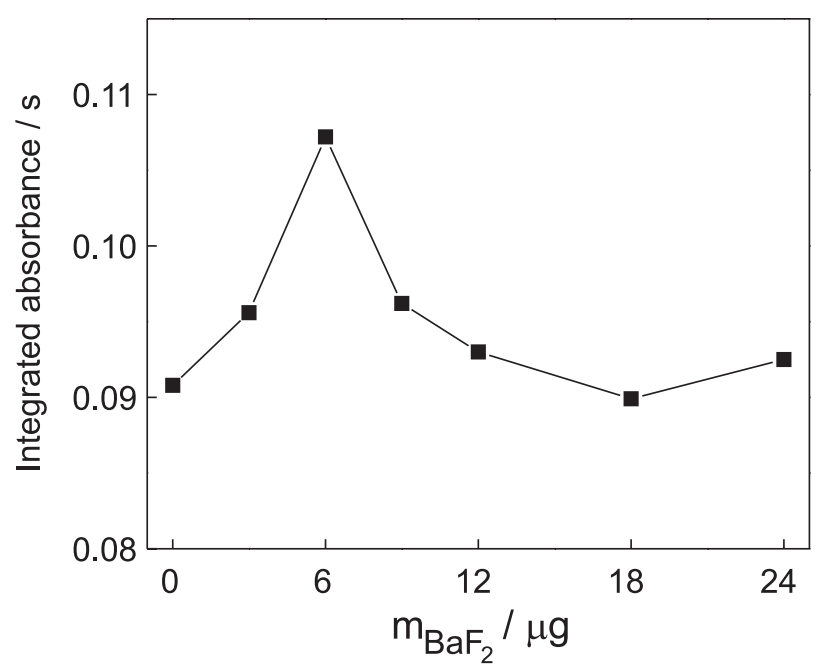

Figure 1. Effect of the mass of barium difluoride on vanadium absorbance signal (sample volume: $60 \mu \mathrm{L}$ and $\mathrm{V}$ concentration: $\left.25 \mu \mathrm{g} \mathrm{L}^{-1}\right)$.

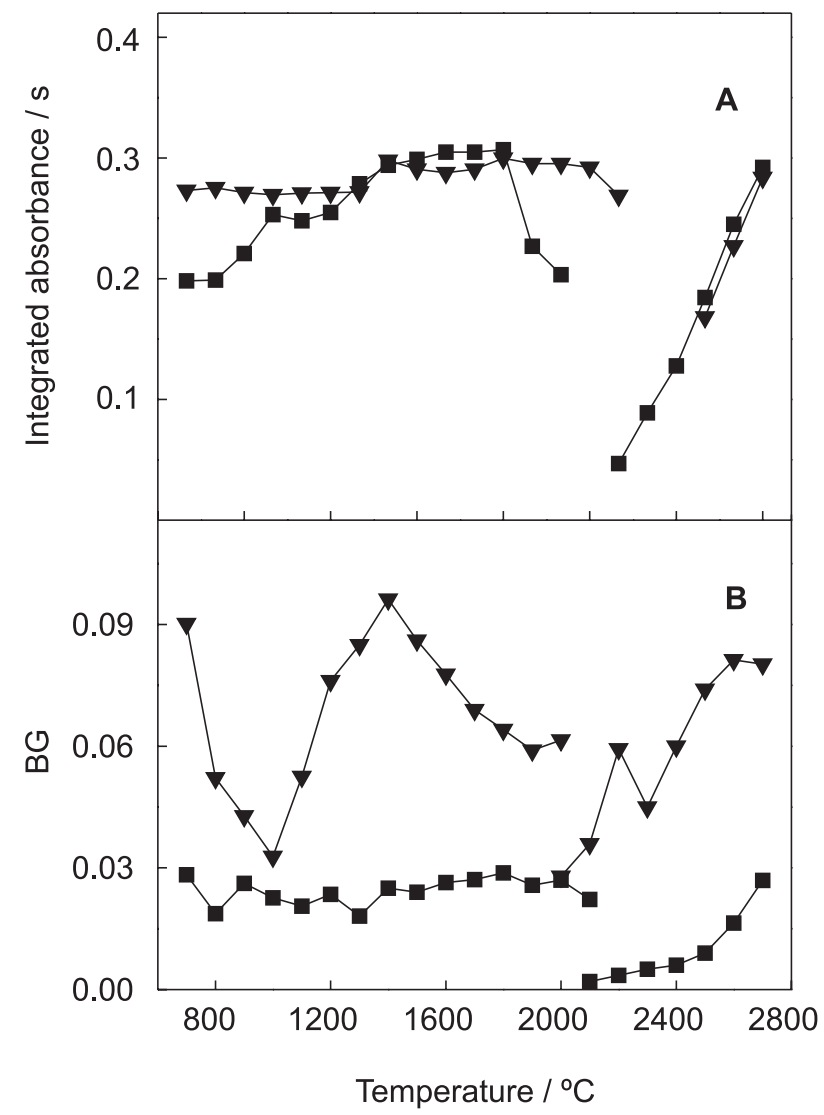

Figure 2. (A) Pyrolysis and atomization curves for $\mathrm{V}$ in urine and $0.014 \mathrm{~mol} \mathrm{~L}^{-1} \mathrm{HNO}_{3}(\boldsymbol{\nabla})$ (B) Background signals. Integrated absorbance refers to $100 \mu \mathrm{g} \mathrm{L}^{-1} \mathrm{~V}$.

temperatures were $1800{ }^{\circ} \mathrm{C}$ and $2700{ }^{\circ} \mathrm{C}$ without or with $\mathrm{BaF}_{2}$. In a medium containing $\mathrm{NH}_{4} \mathrm{NO}_{3}$ pyrolysis and atomization temperatures experimentally established were $1500{ }^{\circ} \mathrm{C}$ and $2700{ }^{\circ} \mathrm{C}$. Background signals obtained for previously cited temperatures were $0.078,0.056$, and 0.052 for urine, either with $\mathrm{BaF}_{2}$, or with $\mathrm{NH}_{4} \mathrm{NO}_{3}$, respectively. In spite of the better sensitivity observed without adding any chemical modifier, the deposition of salts in the tube orifice and graphite electrodes caused memory effects and graphite tube lifetime was 120 firings. In the worst situations even partial obstruction of the optical path occurred. Both chemical modifiers eliminated the deposition of salts but lifetime of the graphite tube was 150 firings in a medium containing $\mathrm{NH}_{4} \mathrm{NO}_{3}$. Thus, further experiments were carried out by adding $6 \mu \mathrm{g} \mathrm{BaF}_{2}$ to urine samples.

\section{Effect of sample volume}

Integrated absorbance signals increased with augment of sample volume. In order to increase sensitivity the introduction of higher volumes of samples in a preheated tube was evaluated. The effect of hot injection into a 


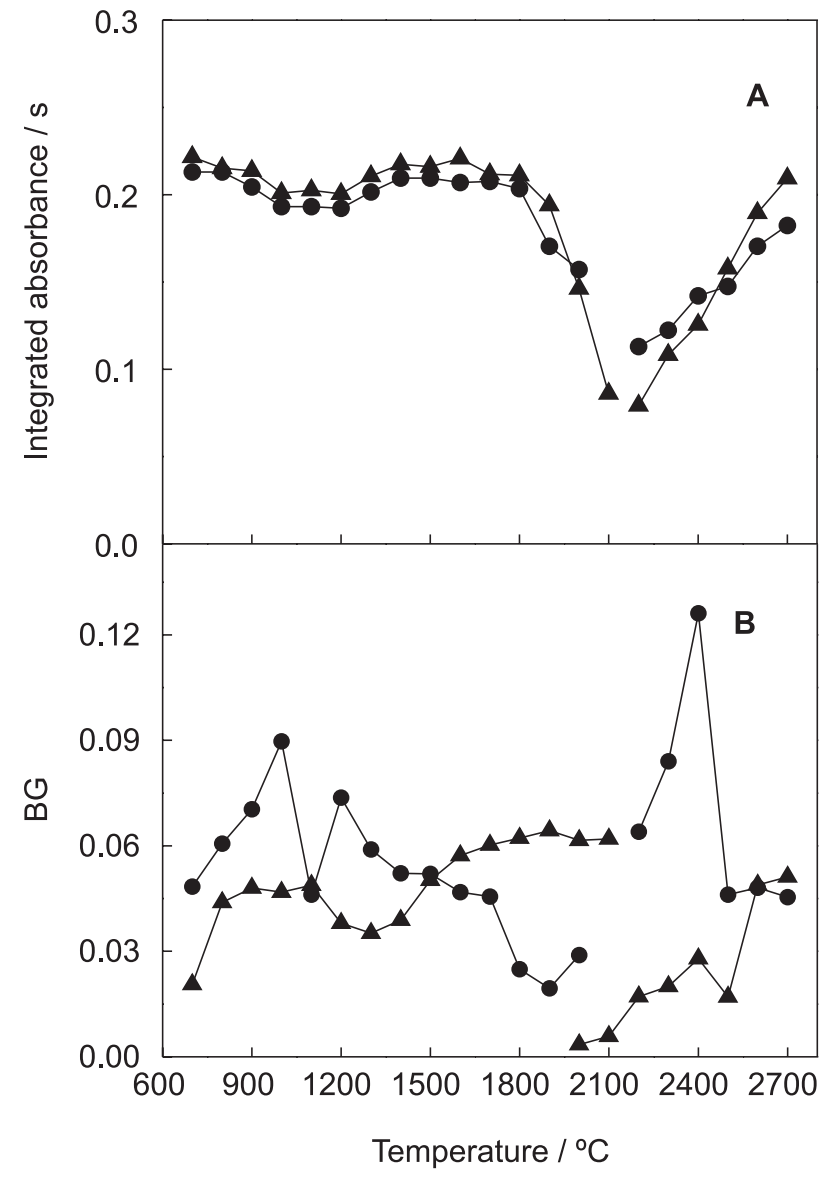

Figure 3. (A) Pyrolysis and atomization curves for $\mathrm{V}$ in urine with $300 \mu \mathrm{g} \mathrm{NH}_{4} \mathrm{NO}_{3}(\bullet)$ and $6 \mathrm{mg} \mathrm{BaF}_{2}(\mathbf{\Delta})$. Integrated absorbance refers to $100 \mu \mathrm{g} \mathrm{L}^{-1} \mathrm{~V}$.

graphite tube on the integrated absorbance signals of $\mathrm{V}$ was studied from 70 to $120^{\circ} \mathrm{C}$ (Figure 4). Better sensitivity was reached at $110{ }^{\circ} \mathrm{C}$. The hot injection increases sensitivity and allows a faster drying step since solvent is at least partially volatilized by introduction at a programmed solution flow-rate. The increment in sensitivity is clearly related to the higher mass of analyte introduced and with the use of hot injection. The reaction: $\mathrm{V}_{2} \mathrm{O}_{3(\mathrm{~s})}+3 \mathrm{C}_{(\mathrm{s})} \rightarrow 2 \mathrm{~V}_{(\mathrm{s})}+3 \mathrm{CO}_{(\mathrm{g})}$, proposed by Styris and Kaye, ${ }^{24}$ may be occurring when using a preheated tube. ${ }^{14}$ Figure 5 shows the effect of sample volume introduced into a graphite tube at room temperature $(10-40 \mu \mathrm{L})$ using $\mathrm{BaF}_{2}$ and Triton X-100 as matrix modifiers and the heating program showed in Table 2 and when solution $(30$ to $70 \mu \mathrm{L}$ ) was introduced into the heated tube kept at $110{ }^{\circ} \mathrm{C}$. The repeatability of measurements may be affected when larger volumes are dispensed into the atomizer. Relative standard deviations (RSDs) of the measurements varied from 1.6 to $5.2 \%$ and 1.5 to $4.1 \%$ without and with preheating for sample volumes of 30 and $70 \mu \mathrm{L}$, respectively $(n=3)$. This procedure can be adopted for improving sensitivity.

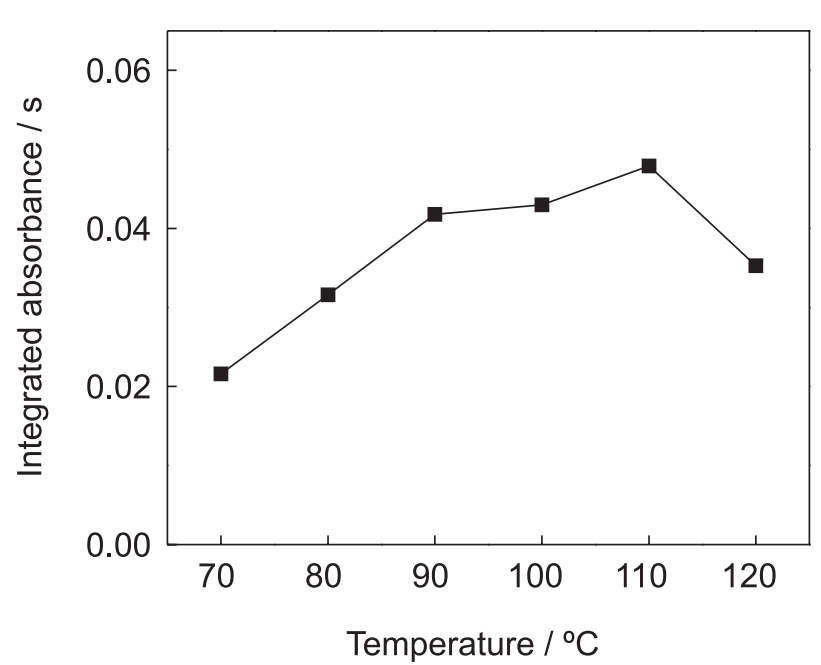

Figure 4. Effect of temperature of the heated tube on absorbance signal (injected sample volume: $30 \mu \mathrm{L}$ and concentration of $\mathrm{V}$ : $\left.20 \mu \mathrm{g} \mathrm{L}^{-1}\right)$.
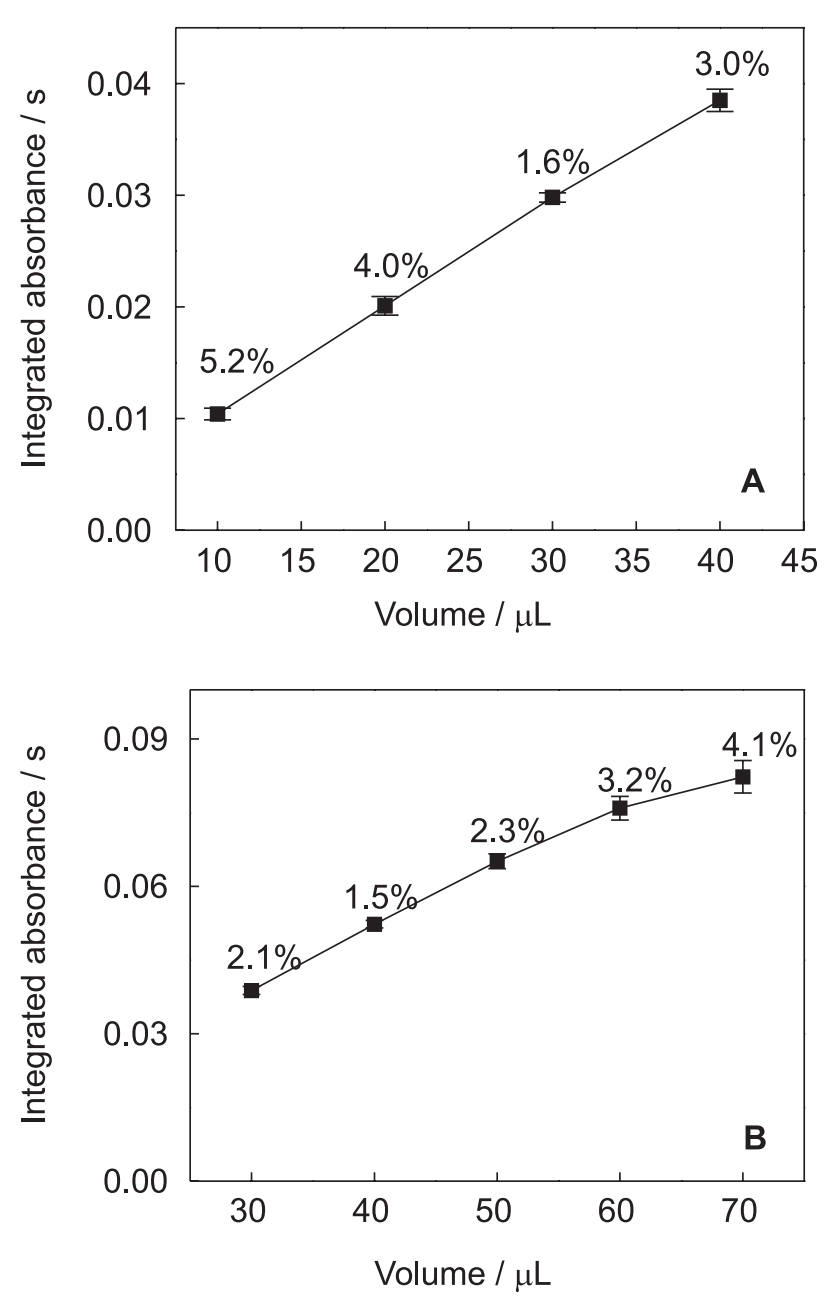

Figure 5. Effect of sample volume introduced into a graphite tube at room temperature (A) and into a graphite tube heated at $110^{\circ} \mathrm{C}(\mathrm{B})$. Integrated absorbance refers to a solution containing $20 \mu \mathrm{g} \mathrm{L}^{-1} \mathrm{~V}$ in $0.014 \mathrm{~mol} \mathrm{~L}^{-1} \mathrm{HNO}_{3}$ with the use of $\mathrm{BaF}_{2}$ as matrix modifier. 
Graphite furnace preconcentration heating program

The typical sensitivity obtained using conventional procedures is not enough for determination of vanadium in urine by ETAAS and the use of a preconcentration step is necessary. A method of sample preconcentration by urine mineralization and vanadium chelation followed by solvent extraction has been described, ${ }^{7}$ but despite its effectiveness it requires many steps that can impair accuracy and precision. Thus it was decided to investigate an in situ preconcentration procedure into the graphite tube using multi-injection into a preheated tube. Triton X-100 was added to each urine sample for improving autosampler action and sample distribution into the tube wall. Volumes of $600 \mu \mathrm{L}$ of urine sample, $100 \mu \mathrm{L}$ of $\mathrm{BaF}_{2}$ solution (1000 $\left.\mathrm{mg} \mathrm{L}^{-1}\right), 100 \mu \mathrm{L}$ of Triton X-100 (3\% v v $\left.{ }^{-1}\right)$ were transferred to the autosampler cup, and the volume was made up to $1000 \mu \mathrm{L}$ with distilled-deionized water. Three $60 \mu \mathrm{L}$ volumes were sequentially injected into the atomizer kept at $110^{\circ} \mathrm{C}$. Drying and pyrolysis steps were applied after each sample aliquot (Figure 6). The experimental conditions adopted are presented in Table 1. All signals were measured as integrated absorbance. When injecting into a hot graphite tube, sample flow-rate was $0.5 \mu \mathrm{L} \mathrm{s}^{-1}$. For a $60 \mu \mathrm{L}$ urine aliquot containing $5.0 \mu \mathrm{g} \mathrm{L}^{-1}$ $\mathrm{V}$ without preconcentration (Figure 7), net absorbance and background signals were 0.027 and 0.050 , respectively. This same solution 3 times preconcentrated (Figure 7) into a preheated graphite tube $(3 \times 60 \mu \mathrm{L})$ generated signals of

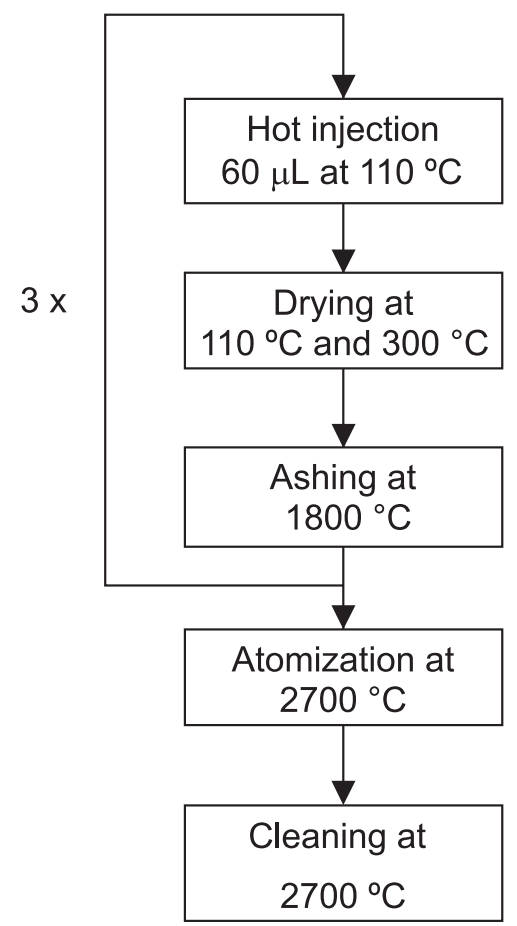

Figure 6. Preconcentration program.
0.090 and 0.123 for net absorbance and background, respectively. The background correction was based on Zeeman effect. The lifetime of the graphite tube under these conditions was about 200 firings.
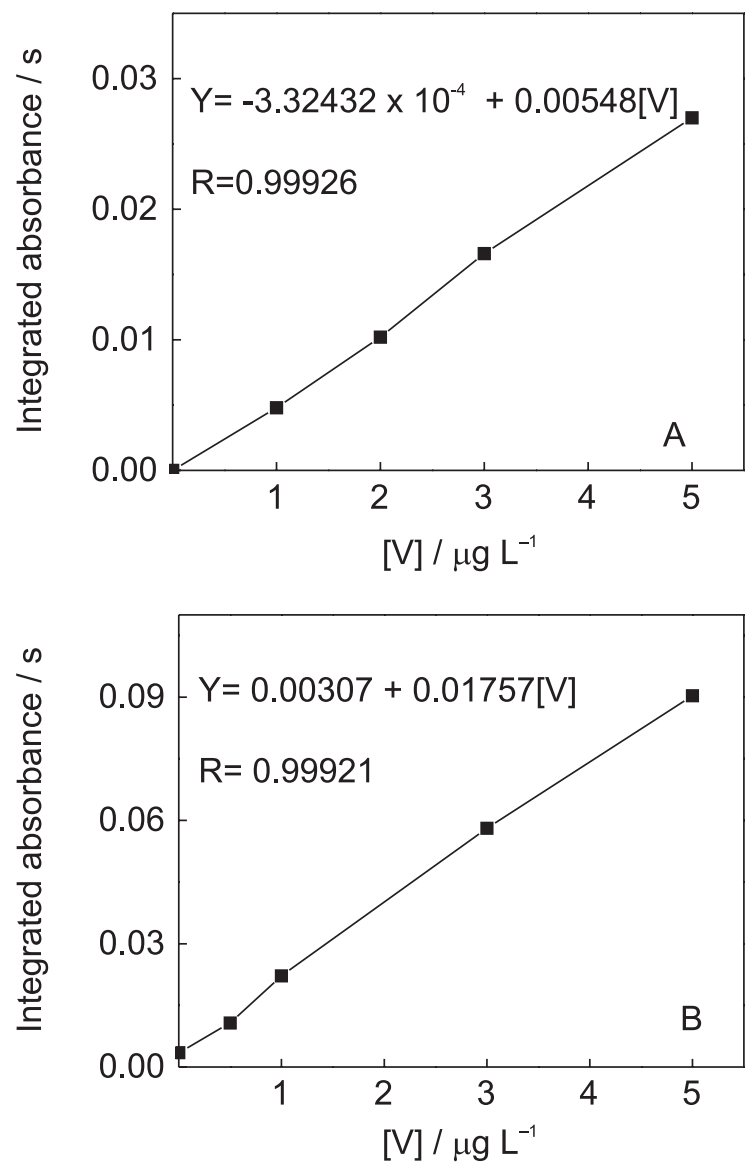

Figure 7. Calibration graph of 1.0-5.0 $\mu \mathrm{g} \mathrm{L}^{-1} \mathrm{~V}$ without (A) and with precontration (B).

\section{Analytical performance}

The matrix effects were evaluated by comparing the slopes for analytical calibration curves built up from aqueous reference solutions and matrix-matched solutions. Sensitivities obtained varied depending on the medium. Hence, calibration based on reference solutions prepared in water is not feasible and the method of matrix matching was therefore used. The analytical curve was obtained by adding appropriate volumes of $\mathrm{BaF}_{2}$ and Triton $\mathrm{X}-100$ solutions in matrix-matched reference solutions containing from 1.0 to $10.0 \mu \mathrm{g} \mathrm{L}^{-1} \mathrm{~V}$. The solvent used in the preparation of all the solutions was a sample of urine containing a vanadium concentration below the detection limit. Good linear correlation coefficient $(r=0.9997)$ was obtained for calibration graph: $\mathrm{Q}_{\mathrm{A}}=2.1 \times 10^{-3}+1.7 \times 10^{-2} c$, where $Q_{A}$ is the integrated absorbance and $c$ is the vanadium concentration. The accuracy of the developed procedure 
was evaluated by an addition-recovery experiment using urine samples. The results obtained are shown in Table 3. Relative standard deviations were always $\leq 4.2 \%(n=10)$. Limits detection $(3 \times \sigma / b)$ and quantification $(10 \times \sigma / b ; \sigma$ : standard deviation; $b$ : linear coefficient of the calibration graph) were 0.54 and 1.82 without preconcentration, and 0.11 and $0.37 \mu \mathrm{g} \mathrm{L}^{-1}$ with preconcentration, respectively $(n=10)$. Characteristic concentration $\left(c_{0}\right)$ and characteristic mass $\left(m_{0}\right)$ were $1.6 \mu \mathrm{g} \mathrm{L}^{-1}$ and $97.8 \mathrm{pg}$ without preconcentration, considering $60 \mu \mathrm{L}$ of sample aliquot. When adopting the procedure with a preconcentration step these values improved to $0.26 \mu \mathrm{g} \mathrm{L}^{-1}$ and $46.8 \mathrm{pg}$, respectively.

Table 3. Added-recovery of $\mathrm{V}$ in urine $(n=3)$

\begin{tabular}{lccr}
\hline & \multicolumn{2}{c}{ Concentration of V $\left(\mu \mathrm{g} \mathrm{L}^{-1}\right)$} & \\
\cline { 2 - 3 } Sample & Added & Found & Rec. $(\%)$ \\
\hline Urine 1 & 0.80 & $0.82 \pm 0.01$ & $103 \pm 1.2$ \\
Urine 2 & 1.50 & $1.51 \pm 0.01$ & $101 \pm 0.7$ \\
Urine 3 & 2.50 & $2.40 \pm 0.02$ & $96 \pm 0.8$ \\
Urine 4 & 3.50 & $3.61 \pm 0.02$ & $103 \pm 0.6$ \\
\hline
\end{tabular}

\section{Conclusions}

Direct determination of vanadium by ETAAS using $\mathrm{BaF}_{2}$ and Triton $\mathrm{X}-100$ as matrix modifiers with preconcentration of the sample directly into the graphite tube is a suitable method for the determination of vanadium in urine samples. The increase of the sensitivity is obtained by injectionns of three successive $60 \mu \mathrm{L}$ aliquots into a preheated tube. The use of $\mathrm{BaF}_{2}$ as a chemical modifier was efficient for improving volatilization of the matrix. The procedure offers several advantages compared to previous ones including fast sample preparation by dilution, reduced possibility of sample contamination caused by manipulation or added reagents, increase of the sensitivity using hot injection into the graphite tube of elevated sample volume, direct preconcentration into the graphite tube and better detection limit than those reported for direct determination procedures. ${ }^{12}$ The procedure developed presents suitable sensitivity, accuracy and precision for determining low vanadium levels in urine.

\section{Acknowledgements}

The authors gratefully acknowledge the financial support provided by Fundação de Amparo à Pesquisa do Estado de São Paulo. K. G. Fernandes, A. R. A. Nogueira, J. A. Gomes Neto, and J. A. Nóbrega would like to thank the Conselho Nacional de Desenvolvimento Científico e Tecnológico for fellowships and grants. The authors also are thankful to Prof. Dr. Pedro V. Oliveira (IQ/USP, São Paulo) by loan of the radiation source.

\section{References}

1. Welz, B.; Sperling, M.; Atomic Absorption Spectrometry, $3^{\text {th }}$ ed., Wiley VCH; Weinheim, 1999.

2. Sabbioni, E.; Kuèera, J.; Pietra, R.; Vesterberg, O.; Sci. Total Environ. 1996, 188, 49.

3. Barceloux, D. G.; Clin. Toxic. 1999, 37, 265.

4. Tsiani, E.; and Fantus, I. G.; Trends Endocrinol. Metab. 1997, 8, 51 .

5. Badmaev, M. D. V.; Prakash, S.; Majeed, M.; J. Altern. Compl. Med. 1999, 5, 273.

6. Poucheret, P.; Verma, S.; Grynpas, M. D.; McNeill, J. H.; Mol. Cell. Biochem. 1998, 188, 73.

7. Arbouine, M. W.; Smith, N. J.; At. Spectrosc. 1991, 12, 54.

8. Ishida, O.; Kihira, K.; Tsukamoto, Y.; Marumo, F.; Clin. Chem. 1989, 35, 127.

9. Apostoli, P.; Alessio, L.; J. Anal. At. Spectrom. 1988, 3, 471.

10. Mousty; F.; Omemetto N.; Pietra, R.; Sabbioni, E.; Analyst 1984, 109, 1451.

11. Krushevska, A.; Waheed, S.; Nóbrega, J.; Amarisiriwardena D.; Barnes, R. M.; Appl. Spectrosc. 1998, 52, 205.

12. Nixon, D. E.; Neubauer, K. R.; Eckdahl, S. J.; Butz, J. A.; Burritt, M. F.; Spectrochim. Acta Part B 2002, 57, 951.

13. Lobinski, R.; Marczenko, Z.; Spectrochemical Trace Analysis for Metals and Metalloids, Elsevier Science: Amsterdam, 1996, p. 777.

14. Bermejo-Barrera, P.; Pardiñas-Alvite, T.; Barciela-Alonso, M. C.; Bermejo-Barrera, A.; Cocho de Juan, J. A.; Fraga-Bermúdez, J. M.; J. Anal. At. Spectrom. 2000, 15, 435.

15. Korkisch, J.; Krivanec, H.; Anal. Chim. Acta 1976, 83, 111.

16. Shriadah, M. M. A.; Ohzeki, K.; Analyst 1985, 110, 677.

17. Murthy, R. S. S.; Ryan, D. E.; Anal. Chem. 1983, 55, 682.

18. Weisel, C. P.; Duce, R. A.; Fasching, J. L. Anal. Chem. 1984, 56, 1050 .

19. Pyy, L.; Hakala, E.; Anal. Chim. Acta 1984, 158.

20. Buchet, J. P.; Knepper, E.; Lauwerys, R.; Anal. Chim. Acta 1982, 136, 243.

21. Ishizaki, M.; Ueno, S.; Talanta 1979, 26, 523.

22. Bermejo-Barrera, P.; Beceiro-Gonzalez, E.; Bermejo-Barrera, A.; Bermejo-Martinez, F.; Analyst 1990, 115, 545.

23. Bermejo-Barrera, P.; Beceiro-Gonzalez, E.; Bermejo-Barrera, A.; Anal. Chim. Acta 1990, 236, 475.

24. Styris D. L.; J. H. Kaye, J. H.; Anal. Chem. 1982, 54, 864.

Received: October 28, 2003

Published on the web: August 17, 2004

FAPESP helped in meeting the publication costs of this article. 